\title{
The Problems of the World of Education in the Middle of the Covid-19 Pandemic
}

\author{
Beby Masitho Batubara \\ Public Administration Study Program, Faculty of Social and Political Sciences, Universitas Medan Area, \\ Indonesia \\ politikbeby@yahoo.co.id
}

\begin{abstract}
Indonesia is the number one country with the highest number of Covid patients in Central Asia. This has an impact on various sectors including the education sector. In Indonesia, approximately 45 million students in Indonesia or it can be said that 3\% of the total data globally, students who cannot take part in learning, the government issued a learning process policy in the midst of a pandemic, this policy determines the learning process which is usually carried out face-to-face, changes be learning online. This research uses a qualitative descriptive approach, with the type of library research, which is the collection of data related to the object of research in the form of literature or studying and deepening the literature literature books, reports and scientific journals, research results and other sources. The obstacles faced in implementing this learning method, namely the unpreparedness of students in the online teaching and learning process, Several studies have stated that not all of the teaching staff in Indonesia in various regions are equalized in carrying out the learning process online based on quality, competency in the use of communication and technology). Not only that, the weak education of the elderly to accompany students in using online media and not supported by facilities to carry out online learning. Dith the provision of internet networks with requiresubstantial costs. The problems in the world of education amid the Covid-19 pandemic must be a serious concern of the central and local governments.
\end{abstract}

Keywords

problematics, education; pandemic covid 19

\section{Introduction}

The country of Indonesia is experiencing a health emergency with the emergence of the corona virus which is a type of pandemic/global disease outbreak that is very rapidly spreading among humans. The government determined that Indonesia was in a conditiondisaster emergency. The forerunner of the covid outbreak in Indonesia, began in early March 2020, the first case of corona in Indonesia, with two Indonesian citizens detected as having contracted the covid-19 virus. The spread of the virus is so fast, causing the number of Covid patients to increase every day and spread to all regions in Indonesia.As of June 22, 2020, Indonesia is the highest country in Southeast Asia with 49,009 positive cases of Covid (www.kompas.com). Real data The number of corona patients is likely to be higher than official government data. This can be seen from the high number of PDP (patients under surveillance) and OTG (people without symptoms) in Indonesia, who have a high risk of reactive corona. The high number of corona patients, which continues to increase every day, has made Indonesia the number one country with the highest number of Covid patients in Central Asia. In addition, based on WHO data, the transmission ratethis virus in Indonesia classified as high, where each Covid patient can transmit the virus to 2 to 5 people. It is almost four months since Indonesia has been in the 
midst of the Covid-19 pandemic, the virus is growing with the number of patients increasing every day and will not stop until a vaccine is found. According to Güçyetmez (2020) The reconsideration and evaluation of the wars of hegemony with Covid 19 pass through the redefinition of the world that has entered the global crisis. Nasution and Dayu in Ekarina (2020) stated that the large number of countries that experienced the Covid-19 case made the World Health Organization (WHO) raise the Covid-19 case from an epidemic to a pandemic.

Story this pandemic ended differently in countries of the world (Lee, 2020), handling and controlling the impact of covid-19 all depend on the policies created and implemented by the government to prevent and control the spread of the virus and its impacts. Therefore,the government applies social distancing and carries out activities at home only. This has an impact on various sectors including the education sector. The world of education has turned around, the covid pandemic has caused a Tsunami of online learning to have occurred almost all over the world during the COVID-19 pandemic (Goldschmidt $\&$ Msn, 2020). In early April, it was predicted that $91.3 \%$ or around 1.5 billion students in various countries would not be able to participate in learning activities due to the increasingly widespread spread of the Covid19 virus (UNESCO, 2020). Including in Indonesia, approximately 45 million students in Indonesia or it can be said that $3 \%$ of the total data globally, students who cannot participate in learning. (Central Statistics Agency, 2020).

The Minister of Education and Culture issued a policy in the form of Minister of Education and Culture Circular Letter Number 3 of 2020 concerning Prevention of COVID-19 in the Education Unit, and Number 36962/MPK.A/HK/2020, this policy stipulates that the learning process that is usually carried out in schools is turned into online learning to avoid an increase in the number of patients caused by Covid 19.).including infrastructure that supports online learning such as facilities and stable networks/signals. (d) the output of learning in the form of products produced by students is assessed qualitatively by assessing various aspects without being required to give a quantitative score (Kemdikbud, 2020).

Based on this policy, it requires that all components in the world of education starting from kindergarten, elementary, junior high school, high school/equivalent to universities must fully utilize technology and the internet as a means and infrastructure in implementing online learning. The Covid-19 pandemic has had a major impact and change for the world of education, including in Indonesia, the corona outbreak is like a big bomb that suddenly causes damage to world globalization (Piliang, 2020). A very sudden change occurred in the education sector to prevent the spread of the virus.

\section{Review of Literature}

This research uses a qualitative descriptive approach, with the type of library research, which is the collection of data related to the object of research in the form of literature or examining and deepening the literature literature books, reports and scientific journals, research results and other sources that are related to the problems involved. researched. Basically, the critical research conducted by researchersstarting from determining the focus of research, the theory used and in-depth information from various literature studies. 


\section{Research Methods}

Online teaching and learning policies using technology that occur suddenly, without preparation or online learning technology preparation before the outbreak occur, must be implemented in all regions in Indonesia. The COVID-19 outbreak prompted testing of distance education almost as never before (Sun et al., 2020). Online learning is also a tangible form of technological development that is not limited to the current 4.0 industrial revolution. Although educators and students cannot meet directly, howeverThe online teaching and learning process is an effective method (Verawardina et al., 2020). If you want it or not, all important elements in the world of education must prepare themselves and technological facilities as the main requirements for online learning.

Teacher or teaching staff is the main part in the implementation of pursuit, a massive change from the traditional/face-to-face teaching and learning process without any preparation to learning that is carried out online (Bao, 2020; Basilaia \& Kvavadze, 2020). The world of campus also experiences the same thing, students who come from various regions, and live temporarily in locations close to the campus to carry out face-to-face academic activities, no longer happen. Since the outbreak appeared in Indonesia and the implementation of online learning policies, all students from the regions who studied at various universities in Indonesia returned to their hometowns. Online learning is the only alternative as a solution to the continued implementation of teaching and learning activities without reducing the time and period of education set out in the previous policy for each student, for example, online lectures are not an obstacle for a student to graduate on time.

Online learning is the only alternative as a solution to keep teaching and learning activities carried out amid the Covid-19 pandemic. The problem is that the government implements an online learning policy as the best solution to prevent the spread of covid-19 and the transfer of knowledge to students can continue. At present, the development of technology is so fast in various countries in the world, online learning does not appear suddenly because of Covid, but has been implemented in several countries even though its implementation is supported by face-to-face learning. So when the pandemic occurs, several countries already have readiness to implement policies online learning such as technology tools, internet, readiness of educational elements (students, teachers/lecturers, parents). This is in contrast to Indonesia's readiness to implement online learning policies. The policy issued by the Ministry of Education and Culture, namely "equitable distribution of technological facilities for the world of education in Indonesia", the Industrial Revolution 4.0 was only felt by the majority of urban communities. Many areas in Indonesia have not yet reached the technology facilities to support the implementation of the online teaching and learning process.

Internet access is one of the main problems of various online learning regions in Indonesia. Apart from that, online learning is also not supported by the readiness of various elements such as teachers/lecturers, students/students, and parents, because this policy is a new thing and there is no technical preparation for the implementation and use of technology in the application of online learning. The government implements social disatncing and physical distancing policies to prevent the prevention of the spread of the Covid-19 pandemic. The world of education as a place of activity for students at every level of education,follow PBM from home through online learning as a solution to the systemeducation is implemented based on standards in effect during a pandemic. Online learning is defined as the experience of transferring knowledge through various media such as images, videos, online communication and other media that support online learning.knowledge of using video, audio, images, text communication, software (Basilaia 
\& Kvavadze, 2020) and supported by internet networks (Zhu \& Liu, 2020). This is part of the modification of the provision of knowledge to students usingwebsite forum (Basilaia \& Kvavadze, 2020), besides that the entry of the world into the 4.0 industrial revolution makes science inseparable from technology as the main support for online learning during this pandemic by creating various learning innovations that are synergized with technology. (Banggur et al., 2018).

Indonesia as a country affected by the corona outbreak, implements learning activities through an online system. The word online stands for "online". The word network indicates that online learning activities are being carried outn through the use of technology and the internet application of systems The learning system using the online method is a system developed by the Ministry of Education and Culture through the Open and Integrated Indonesian Online Lecture Program (KDITT). KDITT is a program implemented for the implementation of online learning on a national scale (Ministry of Education and Culture of the Republic of Indonesia, 2014: 1). Not only in school, the ranks at higher education also implement an online learning process. According to the Ministry of Education and Culture, online lectures are very beneficial for students and tertiary institutions (2014: 16) including 1. Increasing affordable and available academic services besides improving the quality and quality of service and ensuring equality and ensuring good quality for the entire academic community.

There is three indicators that greatly influence success online, namely content, channels, infrastructure or information technology (Tl) (http://fri.or.id). Online teaching and learning activities to run properly must fulfill three components as the main requirements, namely the existence of an internet connection, the existence of technology facilities as a tool and the use of online media, the readiness of teachers/lecturers in providing online teaching. There are other things as additional requirements including, parties who organize online activities, positive thoughts both educators and students about the main benefits of the internet for the learning process, learning process methods that can be understood by all students. As well as monev, a follow-up mechanism for organizers, educators and students. According to Siahaan et al (2020) Educators have a very big role, in addition to being facilitators in student learning, as well as guiding and directing students so that they become human beings who have broad knowledge of both religious knowledge, intelligence, life skills, skills, noble character and good personality and can build themselves to be better than before and have a big responsibility in nation building.

Therefore, online learning that runs smoothly is very much determined by the network (Internet, LAN, WAN) as the main support for supporting educators and students in interacting virtually and the learning process runs well. (http://eyepopping.manilasites.com/profiles/). The benefits of online learning according to Bates and Wulf consist of 4 things, namely: 1) Increasing the level of learning interaction between students and teachers or instructors (enhance interactivity), 2) Enabling learning interactions from where and when (time and place flexibility), 3) Reaching out to students in a broad range (potential to reach a global audience), 4) Facilitating the improvement and storage of learning materials (easy updating of content as well as archivable capabilities) (Bates, 1997: 15). The implementation of the online learning process must provide benefits including improving the quality of both universities and the quality of online learning graduates, thereby providing benefits, including: 1) There is an increase in the quality of higher education and graduate quality graphics, 2) the creation of study groups that are constantly building and sharing knowledge without being limited to the same location, 3) increasing active communication between educators and students, 4) wide range of learning resources, 5) increasing the quality of educators due to the easier get information. 
Adapting Khoe Yao Tung, the characteristics of online learning, include: 1) the material in this learning is in the form of graphics, text and various forms of multimedia elements, 2) the communication formed is carried out simultaneously or not simultaneously depending on the media used, such as virtual video conferencing, forums discussion and discussion room, 3) learning is adjusted to the specified time virtually, 4) besides that learning is also carried out with various elements based on CD-ROOM, which is very useful for creating active communication between students when learning takes place. 5) educators find it easier to update teaching materials, 6) increase interaction between educators and students, 7) form informal and formal communication, 8) the teaching material is wider because it can be obtained from various references on the internet (Tung, 2000: 15). According to Khan BH, there are several things that must be done in online learning including: 1) learning can increase the attention or response of students, 2) students understand the objectives of online learning, 3) Encourage students to know more deeply from the information obtained during the learning process, 4) Provide a stimulus for students, 5) educators provide instructions during online learning, 6) students can perform well, 7) there is an information feedback process, 8) students can provide performance assessments for participants students, 9) increased retention and knowledge transfer. (Khan, 1997: 102).

Infrastructure that supports online learning for free through various discussion spaces such as Google Classroom, Whatsapp, Smart Class, Zenius, Quipper and Microsoft (Abidah et al., 2020). Whatsapp features include Whatsapp Group which can be used to send text messages, images, videos and files in various formats to all members (Kusuma \& Hamidah, 2020). Google Clasroom also allows educators and teachers to develop creative learning.Online discussion by doing face-to-face online is an alternative that really helps the implementation of a quality learning process, many media support face-to-face implementation such as Zoom, Google Meet, CloudX. It is very helpful for students/ students to do percentages online, because they can interact directly face-to-face with teachers/lecturers virtually, this is also one of the variations in online learning.

From the explanation above, it cannot be denied that online learning can be successful, if the education elements have prepared properly the main components in the form of a smooth and stable internet network, technological facilities, the readiness of students and teachers/lecturers as well as learning resources during it online teaching and learning activities.

Online learning policy in Indonesia, which is considered to be the best solution for teaching and learning process withit does not reduce the essence of education amid the covid-19 pandemic, raises problems for the world of education, there is no preparation for fulfilling the main components of online success causing new problems to emerge in the world of education. The unequal use of internet networks and technology facilities causes the ineffectiveness of online learning in most regions in Indonesia. based on datafrom the Indonesian Internet Service Providers Association In 2019, the comparison of data from 2018 to 2019, Java is still the island of Java which is very contributing to the increase in the number of users. from 171.17 million users in 2018, only 55\% increased users outside Java Island which later,Followed by Sumatra Island 21 percent, Sulawesi-MalukuPapua (10\%), Bali-Nusa Tenggara (5\%), (APJII, 2019). In the survey, computer ownership was also uneven. Because based on data Kominfo consists of from Java (11.04 percent), Sumatra (7.63 percent), Kalimantan (8.01 percent), Sulawesi (5.98 percent), MalukuPapua (4.13 percent) and Bali-Nusa Tenggara (5.78 percent ) (Kominfo, 2017). While the $2 \mathrm{G}$ network smartphone ownership survey consisted of Java (51.22 percent), Sumatra (58.13 percent), Kalimantan (57.73 percent), Sulawesi (15.6 percent), Maluku-Papua (39.62 
percent) and Bali-Nusa Tenggara (57.84 percent) (Kominfo, 2017). This indicates the unequal aspects of facilities that can support online learning. The biggest problem in implementing online learning is felt by students who live in rural areas with pre-empire category family economic conditions.

Before the corona outbreak occurred and online learning was implemented, the problem of education in disadvantaged areas had become a never-ending circle. The traditional education system, which has been implemented alone, raises various problems, plus the pandemic condition which requires the use of technology and internet networks creates problems that are very difficult to solve. The topography of Indonesia, which is an archipelago and mountainous country, must be supported by online learning facilities, both cellular telecommunications and the internet. Because the internet with $4 \mathrm{G}$ facilities is still centralized in various areas on the island of Java, besides the high market demands in urban areas in the use of cellular telecommunications, these facilities are also prioritized in urban areas rather than rural areas.(Khatri, 2019). In addition, the problem of online learning has encountered problems in various regions in Indonesia because not all regions have facilities that support this learning, the main factor is the problem of internet networks/signals which suddenly disappear when online learning is taking place (Khasanah et al., 2020)

One of the problems of technological inequality and access to online learning media in various regions in Indonesia, can be proven from the results of research on Innovation for Indonesian School Children (INOVASI), based on the results of a survey of about 300 parents in various districts in the province including NTB, NTT, Kaltara and East Java. The survey results stated that there were problems in online learning that were felt by students who came from families whose economic conditions were below average / group. This has an impact that only $28 \%$ of students are taking online learning. The unpreparedness of students in the online teaching and learning process is due to the various obstacles faced, requiring an increase in the ability and quality of the teaching force as one of the factors that determine the learning process goes well and the achievement of learning objectives for students. Several studies have stated that not all of the teaching staff in Indonesia in various regions are equalized in carrying out the learning process online based on quality, competency in the use of communication and technology (Widodo \& Riandi, 2013 quoted from Koh et al, 2018). Not only technology issues and teacher readiness, parental factors also affect the success of online learning.

In addition, the problem is the lack of education for parents to accompany students in using online media and not supported by facilities to carry out online learning.. (Obiakor \& Adeniran,2020). By providing an internet network with needsubstantial costs. The problems in the world of education amid the Covid-19 pandemic must be a serious concern of the central and local governments. To provide technological facilities and infrastructure, especially in underdeveloped areas and still apply the traditional education system, because the key to online learning is adjustment to the conditions of various regions without eliminating the essence of learning and knowledge transfer for all students.

\section{Conclusion}

The government policy to implement online learning actually provides a solution to keep teaching and learning activities and knowledge transfer to every student amid the conditions of the Covid-19 pandemic. So that the essence of education and the time taken can still be achieved in accordance with the applicable system. Online learning is a problem in the world of education due to the government's unpreparedness in fulfilling the 
main components for the success of the policy. The unequal distribution of facilities and infrastructure with the use of technology occurs in most regions in Indonesia, not only in facilities, the readiness of teachers and parents to support the implementation of online learning is still very minimal. The problem in this world of educationbe the top priority government in equitable education before and in the midst of the Covid-19 pandemic. The government must find alternative solutions so that problems in the world of education can be resolved amid the corona outbreak.

\section{References}

Abidah, A., Hidaayatullaah, H. N., Simamora, R. M., Fehabutar, D., \& Mutakinati, L. (2020). The Impact of Covid-19 to Indonesian Education and Its Relation to the Philosophy of "Merdeka Belajar." Studies in Philosophy of Science and Education, 1(1), 38-49. https://doi.org/https://doi.org/10.15408/sjsb s.v7i3.15104

Asosiasi Penyelenggara Jasa Internet Indonesia. (2019). Survei APJII yang Ditunggutunggu, Penetrasi Internet Indonesia 2018. Asosiasi Penyelenggara Jasa Internet Indonesia

Banggur, M. D. V., Situmorang, R., \& Rusmono. (2018). Pengembangan Pembelajaran Berbasis Blended Learning pada Mata Pelajaran Etimologi Multimedia. JTP -Jurnal Teknologi Pendidikan, 20(2), 152- 165. https://doi.org/10.21009/JTP2002.5

Bao, W. (2020). COVID-19 and online teaching in higher education: A case study of Peking University. March, 113-115. https://doi.org/10.1002/hbe2.191

Basilaia, G., \& Kvavadze, D. (2020). Transition to Online Education in Schools during a SARS-CoV-2 Coronavirus (COVID-19) Pandemic in Georgia. Pedagogical Research, 5(4). https://doi.org/10.29333/pr/7937

Bates, T., The Impact of Technological Change on Open and Distance Learning. Distance Education, 1997.

Goldschmidt, K., \& Msn, P. D. (2020). The COVID-19 pandemic: Technology use to support the wellbeing of children. Journal of Pediatric Nursing, xxxx, 3-5. https://doi.org/10.1016/j.pedn.2020.04.013

Güçyetmez, F., T., Andrabi, J., A., Ridwan, M. (2020). Implications behind the Covid 19: A Profound Structural Change Out Of Catastrophy?. Britain International of Humanities and Social Sciences (BIoHS) Journal, 690-697.

Kemdikbud. Pelaksanaan Kebijakan Pendidikan dalam Masa Darurat Penyebaran Coronavirus Disease (COVID-19). , Pub. L. No. 4 (2020).

Kementerian Pendidikan dan Kebudayaan RI, Panduan Pengembangan dan Penyelenggaraan KDITT, Jakarta: Kemendikbud, 2014.

Khan, B.H., Web Based Instruction, Educational Technology Publications. New Jersey: Englewood Cliffs, 1997). Tung, Khoe Yao, Pendidikan dan Riset di Internet, Jakarta: Dinastindo, 2000.

Khasanah, D. R. A. U., Pramudibyanto, H., \& Widuroyekti, B. (2020). Pendidikan Dalam Masa Pandemi Covid-19. Jurnal Sinestesia, 10(1), 41-48.

Khatri, H. (2019). Indonesian users in sparsely-populated urban areas connect to 4G more than $70 \%$ of the time. Opensignal. Diambil dari: https://www.opensignal.com/2019/11/12/indonesian-users-in-sparsely-populatedrural-areas-connect-to4g-more-than-70-of-the-time

Kominfo. (2017). Survei Penggunaan TIK serta Implikasinya terhadap Aspek Sosial Budaya Masyarakat. Retrieved from balitbangsdm.kominfo.go.id Pembatasan Sosial Berskala Besar dalam Rangka Percepatan Penanganan 
Kusuma, J. W., \& Hamidah. (2020). Platform Whatsapp Group Dan Webinar Zoom Dalam Pembelajaran Jarak Jauh Pada Masa Pandemik Covid 19. Jurnal Ilmiah Pendidikan Matematika Volume, 5(1).

Lee, A. (2020). Wuhan novel coronavirus (COVID-19): why global control is Jurnal Teknologi Pendidikan Vol. 22, No. 1, April 202070 challenging? Public Health, January, 19-21. https://doi.org/https://doi.org/10.1016/j.puh e.2020.02.001

Nasution, M., S., A., Dayu, W. (2020). Fiqh Fardhu Kifayah for the City of Covid-19 According to the Fatwa of MUI and Permenkes Number 413 (Maqashid Syariah Analysis). Budapest International Research and Critics Institute-Journal (BIRCIJournal), 3005-3016.

Obiakor, T., \& Adeniran, A. (2020). Covid-19: Impending Situation Threatens To Deepen Nigeria' S Education Crisis. Center For The Study Of The Economies Of Africa.

Piliang, Y. A. (2020). Virus De-Globalisasi. https://sumbarsatu.com/berita/22657- virusdeglobalisasi

Siahaan, et al. (2020). Innovation of the Use of Education Games Method Utilizing a Thousand of Nail Media in Fiqh Lesson Madrasah Ibtidaiyah Amaliyah Pematangsiantar District. Budapest International Research and Critics in Linguistics and Education (BirLE) Journal, 1558-1563.

Statistics Indonesia. (2020). Potret Pendidikan Indonesia Statistik Pendidikan 2019. BPS: Jakarta. Diambil dari: ht t p s : / / w w w. b p s . g o . id / p u b lic a t i o n / d o w n 1 o a d

Sun, L., Tang, Y., \& Zuo, W. (2020). Coronavirus pushes education online. Nature Materials, 20200205. https://doi.org/10.1038/s41563-020-0678-8

Verawardina, U., Asnur, L., Lubis, A. L., \& Hendriyani, Y. (2020). Reviewing Online Learning Facing the Covid-19 Outbreak. 12(3), 385-392.

Widodo, A., \& Riandi. (2013). Dual-mode teacher professional development: challenges and re-visioning future TPD in Indonesia. Teacher Development, 17(3), 380-392

Zhu, X., \& Liu, J. (2020). Education in and After Covid-19: Immediate Responses and LongTerm Visions.

http://eyepopping.manilasites.com/ profiles/.

www.compas.com 